\title{
Analysis of key molecules of the innate immune system in mammary epithelial cells isolated from marker-assisted and conventionally selected cattle
}

\author{
B. Griesbeck-Zilch, ${ }^{*}$ M. Osman,† Ch. Kühn,‡ M. Schwerin,‡ R. H. Bruckmaier,§ M. W. Pfaffl,, \\ A. Hammerle-Fickinger, ${ }^{*}$ H. H. D. Meyer, ${ }^{*}$ and 0. Wellnitz $\S^{1}$ \\ ${ }^{*}$ Physiology Weihenstephan, Technical University Munich, D-85350 Freising, Germany \\ †Chair of Animal Breeding, Technical University Munich, D-85350 Freising, Germany \\ $\ddagger$ Research Institute for the Biology of Farm Animals, D-18196 Dummerstorf, Germany \\ $\S$ Veterinary Physiology, Vetsuisse Faculty, University of Bern, CH-1725 Posieux, Switzerland
}

\section{ABSTRACT}

Mastitis is the most prevalent infectious disease in dairy herds. Breeding programs considering mastitis susceptibility were adopted as approaches to improve udder health status. In recent decades, conventional selection criteria based on phenotypic characteristics such as somatic cell score in milk have been widely used to select animals. Recently, approaches to incorporate molecular information have become feasible because of the detection of quantitative trait loci (QTL) affecting mastitis resistance. The aims of the study were to explore molecular mechanisms underlying mastitis resistance and the genetic mechanisms underlying a QTL on Bos taurus chromosome 18 found to influence udder health. Primary cell cultures of mammary epithelial cells from heifers that were selected for high or low susceptibility to mastitis were established. Selection based on estimated pedigree breeding value or on the basis of marker-assisted selection using QTL information was implemented. The mRNA expression of 10 key molecules of the innate immune system was measured using quantitative real-time PCR after 1, 6, and $24 \mathrm{~h}$ of challenge with heat-inactivated mastitis pathogens (Escherichia coli and Staphylococcus aureus) and expression levels in the high and low susceptibility groups were compared according to selection criteria. In the marker-assisted selection groups, mRNA expression in cells isolated from less-susceptible animals was significantly elevated for toll-like receptor 2, tumor necrosis factor- $\alpha$, IL-1 $\beta$, IL-6, IL-8, RANTES (regulated upon activation, normal t-cell expressed and secreted), complement factor $\mathrm{C} 3$, and lactoferrin. In the estimated pedigree breeding value groups, mRNA expression was significantly elevated only for V-rel reticuloendothelio-

Received December 8, 2008

Accepted May 27, 2009.

${ }^{1}$ Corresponding author: olga.wellnitz@physio.unibe.ch sis viral oncogene homolog A, IL-1 $\beta$, and RANTES. These observations provide first insights into genetically determined divergent reactions to pathogens in the bovine mammary gland and indicate that the application of QTL information could be a successful tool for the selection of animals resistant to mastitis.

Key words: quantitative trait locus, mastitis, mammary epithelial cell, dairy cattle

\section{INTRODUCTION}

Mastitis, an inflammation of the udder caused by invading pathogens, is one of the most important infectious diseases in dairy production. Aside from effects on animal welfare, potential damage to human health caused by food-borne pathogens and economic losses in milk production are the main reasons for intensive research in this topic (Seegers et al., 2003).

During the last decades, the main breeding goal in dairy cattle was to improve milk yield using different conventional selection indices (Miglior et al., 2005). However, there is an unfavorable genetic correlation between milk yield and mastitis susceptibility leading to an increased frequency of this disease (Rupp and Boichard, 2003; Hinrichs et al., 2005). Because of the limited progress in improving udder health by conventional selection procedures using solely indirect traits like SCS in milk, there was an increasing demand for molecular marker information on mastitis susceptibility to be included in marker-assisted selection schemes. In the literature (as reviewed in Khatkar et al., 2004), a large number of QTL are reported to affect mastitis incidence or SCS in milk, a surrogate trait describing udder health (Klungland et al., 2001). One of the bestconfirmed QTL affecting udder health is located in the telomeric region of Bos taurus chromosome (BTA) 18 (Kühn et al., 2003; Schulman et al., 2004; Xu et al., 2006). A previous study (Kühn et al., 2008) used the respective molecular marker information to successfully 
select primiparous heifers for low or high susceptibility to mastitis before their first calving. This strategy highlights the potential for using molecular marker information as an enhanced selection tool for animals. However, the chromosomal region corresponding to the confidence interval of the QTL location on BTA 18 contains a large number of genes because of a high gene density in the respective chromosomal region. Information about molecular mechanisms underlying mastitis susceptibility in general and specifically for this QTL is still scarce. Furthermore, complex regulatory interactions of this QTL with other regions of the genome are possible. Thus, in this study, well-known elements of the innate immunity system were tested independently of their positional background as to whether they are affected by animal selection for high or low mastitis susceptibility.

Together with udder and teat morphology or milking speed, innate immunity is the first line of defense against invading pathogens, and consequently has a major influence on mastitis susceptibility (Rainard and Riollet, 2006). Epithelial cells covering the inner surface of the mammary gland play a crucial role in early interactions between pathogen and host because they build the ultimate barrier between the outside environment and the body interior (Korhonen et al., 2000). In particular, epithelial cells synthesize toll-like receptors (TLR) such as TLR2 and TLR4, recognizing microorganisms causing mastitis (Rainard and Riollet, 2006). Activation of the TLR leads to the release of the transcription factor, nuclear factor- $\kappa \mathrm{B}$, consisting of $\mathrm{V}$-rel reticuloendotheliosis viral oncogene homolog A (RelA) and other subunits. Nuclear factor- $\kappa$ B, in turn, translocates into the nucleus and regulates expression of a large number of proinflammatory signaling molecules that are essential for initiating local and systemic immune reactions of the animal (Pahl, 1999; Liang et al., 2004). These include cytokines, such as tumor necrosis factor- $\alpha$ (TNF- $\alpha$ ), IL-1 $\beta$, IL-6, and chemokines, such as IL-8 and RANTES (regulated upon activation, normal T-cell expressed and secreted) (Boudjellab et al., 2000; Riollet et al., 2000; Persson Waller et al., 2003; Bannerman et al., 2004; Pareek et al., 2005). Furthermore, mammalian epithelial cells also express complement factor $\mathrm{C} 3$ and lactoferrin, 2 important components of the innate immune defense of the udder (Hagiwara et al., 2003; Pfaffl et al., 2003; Rainard, 2003; Schmitz et al., 2004).

In this investigation, mammary epithelial cells isolated from animals selected for high and low susceptibility to mastitis by the 2 different selection strategies were challenged with heat-inactivated Staphylococcus aureus and Escherichia coli. Staphylococcus aureus, a gram-positive pathogen, is the predominant pathogen in chronic mastitis that can persist for the life of the animal. Escherichia coli, a gram-negative pathogen, is often isolated from acute forms of mastitis. The focus of this study is on the effect of pathogen challenge on expression of these genes of the innate immune response in animals divergently selected for high and low susceptibility to mastitis according to conventional and marker-assisted selection criteria. The results of this study are expected to contribute toward a better understanding, at the level of mammalian epithelial cells, of the genetically determined mechanisms underlying differences in immunological responses of individual animals.

\section{MATERIALS AND METHODS}

All heifers were kept under the national guidelines for animal experiments and according to standard dairy farm practice without any intervention in the living animal. The study was approved by an institutional committee. All individuals were slaughtered according to protocols for certified European slaughterhouses under the federal control of an independent veterinarian.

\section{Selection of Animals}

The selection of heifers for high and low susceptibility to mastitis was performed as described in a previous study (Kühn et al., 2008). Heifers were selected from the entire German Holstein population. The initial selection identified heifers born between February and September 2003, which were sired for first parturition in a time interval of 6 weeks between December 2004 and February 2005 and had a complete 3-generation pedigree including performance traits.

Starting from this large pool of heifers, 2 different selection strategies for high and low susceptibility to mastitis as reflected in SCS were applied. The conventional selection strategy relied exclusively on relative EBV for SCS (RZS) estimated in the routine breeding evaluation (VIT, Verden, Germany; www.vit.de). The RZS represent the reverse of the SCS EBV to indicate undesirable progeny tests with values below 100. The conventional strategy comprised one progeny group (designated CON-Q) originating from sires with extremely high RZS and one progeny group (designated CON-q) originating from sires with extremely low RZS. Furthermore, maternal grandsires (MGS) of the selected daughters were required to show the same direction for RZS as the respective sires, and the dams themselves had to have a relative breeding value for SCS at least equal to their sire (the MGS). In addition to RZS, selection in these groups also considered information on milk flow of the sire and MGS to avoid 
undesirable low milk flow in the CON-Q group caused by the established negative genetic correlation between milk flow and SCS (Rupp and Boichard, 2003). Thus, daughters from sires with extremely negative $(\mathrm{CON}-\mathrm{Q}$ group) or extremely positive (CON-q group) breeding values for milk flow were excluded. Selection resulted in 7 animals classified as presumably very susceptible regarding mastitis (CON-q) and 10 heifers as presumably less susceptible (CON-Q) according to parental pedigree information on SCS.

In contrast to the conventional strategy, the markerassisted selection strategy primarily relied on marker information regarding paternally inherited marker alleles for selection. Three sires were selected from the German Holstein population, with an RZS value close to the average of the sire population, but displayed a difference of at least $1 / 3 \mathrm{~s}_{\mathrm{a}}$ (genetic standard deviation under an additive genetic model) in their marker-assisted BLUP breeding value for SCS at their alternative chromosomes in the telomeric region of BTA 18. Marker-assisted BLUP calculation was performed essentially according to Fernando and Grossman (1989) merging pedigree, phenotype, and genotyping data from the German Holstein population at the central database at the VIT (Wilkens et al., 2006). The telomeric region had previously been shown to harbor a confirmed QTL affecting somatic cell score (Kühn et al., 2003; Xu et al., 2006). The large difference in alternative sire haplotype effects were taken as indication that the respective sires were presumably heterozygous at the QTL affecting SCS on BTA 18. For each of the 3 sires, daughters that were preselected to fulfill the requirements regarding age and time of parturition (see above) and the dams of these daughters (when available) were genotyped for 5 microsatellite markers (BM7109, ILSTS002, BMS2639, BM2078, TGLA227) as described in Xu et al. (2006). The most likely paternal haplotypes were calculated from the genotypes of the daughter groups according to Weikard et al. (2005), assuming the marker order in Xu et al. (2006). Information on marker-QTL allele linkage phase from the marker-assisted BLUP evaluation was used to assign QTL alleles to the respective paternal marker haplotypes. After the inherited paternal marker haplotype (and thus indirectly the inherited paternal QTL allele) of a heifer was inferred, heifers were assigned to the groups designated MAS-Q (inheriting the paternal chromosomal region decreasing SCS) and MAS-q (inheriting the paternal chromosomal region increasing SCS) according to the marker haplotype (and putative QTL allele) they inherited from the sire. The groups MAS-Q and MAS-q comprised 6 and 5 heifers, respectively, which were predicted to differ substantially in their susceptibility regarding mastitis (with MAS-q being less susceptible than MAS-Q).
All 28 heifers selected (10 CON-Q, 7 CON-q, 6 MAS$\mathrm{Q}$, and 5 MAS-q) were born and reared on ordinary dairy farms that were distributed over 11 regions in Germany. They were brought together in their seventh month of gestation at the Research Institute for the Biology of Farm Animals, Dummerstorf. To control for extraneous sources of variation, all animals were kept under the same environmental conditions. Following parturition, udder health was inspected weekly by measuring SCS in milk samples and by clinical investigations. Milk samples from each quarter were tested for bacterial infection on slaughtering day. Monitoring of the heifers postpartum verified that indeed there were differences in SCS between the MAS-Q and the MAS-q group and the CON-Q and CON-q group (q groups showed greater SCS than Q groups) as assumed in the selection strategy (Kühn et al., 2008). Those differences were more pronounced for the MAS groups. All heifers included in the study were clinically healthy and did not show any indication of bacterial infection on the day of slaughter $42 \mathrm{~d}$ postpartum.

\section{Primary Cell Culture of Mammary Epithelial Cells}

All animals were slaughtered on d 42 of their first lactation. Primary cell cultures from the mammary gland epithelial cells were obtained as described previously (Wellnitz and Kerr, 2004) with slight modifications. Immediately after the animal was slaughtered, a deep sagittal section was made through one quarter of the udder and 2 pieces of about $1.5 \times 1.5 \times 1.5$ $\mathrm{cm}$ were taken as aseptically as possible from the parenchyma. Samples were transported to the laboratory in $200 \mathrm{~mL}$ of room-temperature Hanks' balanced salt solution (HBSS; Sigma-Aldrich, Munich, Germany) containing $200 \mu \mathrm{g}$ of penicillin/mL, $200 \mu \mathrm{g}$ of streptomycin/mL, $200 \mu \mathrm{g}$ of gentamicin/mL, and $10 \mu \mathrm{g}$ of amphotericin B/mL (Sigma-Aldrich). The tissue was minced and blood and milk residues were flushed away with HBSS. Samples were transferred to a digestion mix consisting of $200 \mathrm{~mL}$ of HBSS, $0.5 \mathrm{mg}$ of collagenase $\mathrm{IA} / \mathrm{mL}, 0.4 \mathrm{mg}$ of DNase type $\mathrm{I} / \mathrm{mL}, 0.5 \mathrm{mg}$ of hyaluronidase/mL (enzymes from Sigma-Aldrich), and the same antibiotics mentioned above, and placed in a shaking incubator at $37^{\circ} \mathrm{C}$ for $165 \mathrm{~min}$. Cells were separated from connective tissue and nonepithelial cell conglomerates by filtration and centrifugation $(40 \times g$; $4 \mathrm{~min}$ ). The pellet was resuspended with HBSS and the procedure was repeated 2 times each with a strainer of a decreasing pore size (smallest pore size $100 \mu \mathrm{m}$; BD Biosciences, Erembodegem, Belgium). The final pellet was resuspended in Dulbecco's modified Eagle's medium nutrient mixture F-12 Ham (DMEM/F12; Sigma-Aldrich) which contains penicillin, streptomycin, 
gentamicin, and amphotericin B in the same concentrations as previously described, as well as $10 \%$ fetal bovine serum (FBS) and $10 \mu \mathrm{L}$ of ITS/mL (ITS: 0.5 $\mathrm{mg}$ of bovine insulin/mL, $0.5 \mathrm{mg}$ of apo-transferrin/ $\mathrm{mL}, 0.5 \mu \mathrm{g}$ of sodium selenite $/ \mathrm{mL}$; Sigma-Aldrich) and was incubated in a $75 \mathrm{~cm}^{2}$ tissue culture flask (Greiner bio-one, Frickenhausen, Germany) for $40 \mathrm{~min}$ at $37^{\circ} \mathrm{C}$, $5 \% \mathrm{CO}_{2}$, and $90 \%$ humidity. After this time, fibroblasts had attached and epithelial cells could be isolated by decanting. Cells were seeded in $25 \mathrm{~cm}^{2}$ tissue culture flasks (Greiner bio-one) and cultured until they reached about $80 \%$ confluence. They were then cryopreserved at $-80^{\circ} \mathrm{C}$ in $1 \mathrm{~mL}$ of freezing medium containing DMEM/ F12, 20\% FBS, and 10\% dimethyl sulfoxide. To verify the epithelial origin of the cells, an immunocytochemical staining of cytoceratins characterizing this cell type was conducted randomly as described by Wellnitz and Kerr (2004). The predominant cell type was represented by epithelial cells (approximately 90 to $95 \%$ ).

\section{Treatment of Epithelial Cells with Mastitis Pathogens}

One colony of Staph. aureus M60 (Bramley et al., 1989) and E. coli, respectively, each isolated from a milk sample obtained from an udder with bovine mastitis and verified by a standard protocol, was incubated overnight in Luria-Bertani (E. coli) or tryptone-soy broth (Staph. aureus) medium at $37^{\circ} \mathrm{C}$ and diluted 1:1,000 with the respective medium on the next day. Bacteria were kept under cultivation conditions until an optical density of 0.1 to 0.25 at $600 \mathrm{~nm}$ was reached. Plate dilution was used for defining concentrations. Heat inactivation of the pathogens was conducted at $63^{\circ} \mathrm{C}$ for $30 \mathrm{~min}$ to prevent bacterial overgrowth in the cell culture medium and to assure a constant and comparable infection challenge for both pathogens over $24 \mathrm{~h}$. Inactivation efficiency was tested on blood agar plates.

Epithelial cells were thawed and cultured under cultivation conditions $\left(37^{\circ} \mathrm{C}, 5 \% \mathrm{CO}_{2}\right.$, and $90 \%$ humidity) in DMEM/F12 medium containing $100 \mu \mathrm{g}$ of penicillin/ $\mathrm{mL}, 100 \mu \mathrm{g}$ of streptomycin/mL, $100 \mu \mathrm{g}$ of gentamicin/ $\mathrm{mL}, 5 \mu \mathrm{g}$ of amphotericin/mL, 10\% FBS, and $10 \mu \mathrm{L}$ of ITS $/ \mathrm{mL}$ for 2 further passages and then seeded in three 6-well tissue culture plates (Greiner bio-one) in a concentration of 300,000 cells/well for 1-, 6-, and 24-h analysis. In each plate, 2 wells were prepared for control, and 2 each for Staph. aureus and E. coli treatment. On the following day, the medium was replaced by DMEM/F12 supplemented with ITS only. On the second day after seeding, at a confluence of about $70 \%$, this medium was refreshed and $100 \mu \mathrm{L}$ of bacterialsolution representing a multiplicity of infection of 10 , according to Wellnitz et al. (2006) was added. Control cells were treated only with $100 \mu \mathrm{L}$ of PBS.

\section{Real-Time PCR for mRNA Quantification}

After 1, 6, and $24 \mathrm{~h}$, cells were harvested and total RNA was extracted with the TriFast reagent (PeqLab, Erlangen, Germany) as prescribed in manufacturer's instructions. For converting the RNA template in cDNA, $1 \mu \mathrm{g}$ of RNA was reverse transcribed by using $200 \mathrm{U}$ of M-MLV reverse transcriptase RNase (H-; Promega, Mannheim, Germany) using $50 \mu M$ of random primers (Invitrogen, Karlsruhe, Germany) and $10 \mathrm{~m} M$ of dNTPs (Fermentas, St. Leon-Rot, Germany) according to the manufacturer's instructions. A negative control was added without enzyme to detect DNA contaminations in the RNA. For the $\mathrm{qPCR}$ reaction, $2 \mu \mathrm{L}$ of $\mathrm{cDNA}$ equivalent to $16.66 \mathrm{ng}$ of total RNA was amplified in a $15-\mu \mathrm{L}$ reaction volume with the Mastercycler Realplex (Eppendorf, Hamburg, Germany) using Realmastermix (Eppendorf, Hamburg, Germany) and $7.5 \mathrm{n} M$ of reverse and forward primer each. Here a further negative control was included by measuring 1 sample containing water instead of cDNA. Primers were designed with online primer-design software (MWG Biotech, Ebersberg, Germany) and synthesized by MWG Biotech. Sequences, accession numbers of the PCR primers, and length of the PCR products are shown in Table 1. The following protocol was used: denaturation $\left(95^{\circ} \mathrm{C}\right.$, $2 \mathrm{~min})$, cycling program $\left(95^{\circ} \mathrm{C}, 5 \mathrm{~s} ; 60^{\circ} \mathrm{C}\left(62^{\circ} \mathrm{C}\right), 10 \mathrm{~s}\right.$; $68^{\circ} \mathrm{C}, 2 \mathrm{~s}$ ) and melting curve analysis. The $\mathrm{C}_{\mathrm{T}}$ (cycle threshold) value of a sample was set at the cycle number at which fluorescence signal intersected with the threshold. The threshold was determined automatically by the CalQplex Realplex software (Version 1.5; Eppendorf, Ebersberg, Germany), including efficiency of amplification so that the threshold was significantly above baseline noise. Predicted size of PCR-products was tested by agarose gel electrophoresis after ethidium bromide staining.

\section{Selection of Target Genes}

This study was initiated to receive indications of the functional mechanisms in immune defense modulated by the QTL on BTA 18. In the targeted region on BTA 18 there are numerous candidate genes, mostly with unknown functions in the complex network of immune defense. Furthermore, complex regulatory interactions with other regions in the genome are presumed to be present. Thus, well-known stages of the innate immunity were examined to test whether they were affected by the animal selection procedure. To achieve this, sev- 
Table 1. Sequences, accession numbers of the PCR primers, and length of the PCR products

\begin{tabular}{|c|c|c|c|c|}
\hline Primer & Sequence & $\left.3^{\prime}\right)$ & Accession no. & Length (bp) \\
\hline Glyceraldehyde-3-phosphate dehydrogenase & $\begin{array}{l}\text { forward } \\
\text { reverse }\end{array}$ & GTC TTC ACT ACC ATG GAG AAG G & NM001034034 & 201 \\
\hline Tyrosine 3-monooxygenase/tryptophan 5-monooxygenase activation protein & $\begin{array}{l}\text { forward } \\
\text { reverse }\end{array}$ & $\begin{array}{l}\text { CAG GCT GAG CGA TAT GAT GAC } \\
\text { GAC CCT CCA AGA TGA CCT AC }\end{array}$ & BC102382 & 141 \\
\hline Ubiquitin & $\begin{array}{l}\text { forward } \\
\text { reverse }\end{array}$ & $\begin{array}{l}\text { AGA TCC AGG ATA AGG AAG GCA T } \\
\text { GCT CCA CTT CCA GGG TGA T }\end{array}$ & NM174133 & 198 \\
\hline V-rel reticuloendotheliosis viral oncogene homolog A & $\begin{array}{l}\text { forward } \\
\text { reverse }\end{array}$ & $\begin{array}{l}\text { CAT TCC CTG GCA AGT GGA TTA TC } \\
\text { GGA ATG GCC TTC TTG TCA ATG G }\end{array}$ & AY634629 & 201 \\
\hline Toll-like receptor 2 & $\begin{array}{l}\text { forward } \\
\text { reverse }\end{array}$ & $\begin{array}{l}\text { TAT GAA CCA CTC CAC TCG CTC } \\
\text { CAT CAT TTG CTC AGC TCC CAC }\end{array}$ & DQ839566 & 207 \\
\hline Toll-like receptor 4 & $\begin{array}{l}\text { forward } \\
\text { reverse }\end{array}$ & $\begin{array}{l}\text { GCC GAG GCT CTT TTT CAC AAG } \\
\text { TCT GGC AAG TAC TGG AAT TCC }\end{array}$ & XM584983 & 169 \\
\hline Tumor necrosis factor $\alpha$ & $\begin{array}{l}\text { forward } \\
\text { reverse }\end{array}$ & $\begin{array}{l}\text { CCA CGT TGT AGC CGA CAT C } \\
\text { CCC TGA AGA GGA CCT GTG AG }\end{array}$ & NM173966 & 155 \\
\hline Interleukin-1 $\beta$ & $\begin{array}{l}\text { forward } \\
\text { reverse }\end{array}$ & $\begin{array}{l}\text { AGT GCC TAC GCA CAT GTC TTC } \\
\text { TGC GTC ACA CAG AAA CTC GTC }\end{array}$ & M37211 & 114 \\
\hline Interleukin-6 & $\begin{array}{l}\text { forward } \\
\text { reverse }\end{array}$ & $\begin{array}{l}\text { GCT GAA TCT TCC AAA AAT GGA GG } \\
\text { GCT TCA GGA TCT GGA TCA GTG }\end{array}$ & NM173923 & 215 \\
\hline Interleukin-8 & $\begin{array}{l}\text { forward } \\
\text { reverse }\end{array}$ & $\begin{array}{l}\text { ACA CAT TCC ACA CCT TTC CAC } \\
\text { ACC TTC TGC ACC CAC TTT TC }\end{array}$ & AF232704 & 149 \\
\hline Regulated upon activation, normal t-cell expressed and secreted & $\begin{array}{l}\text { forward } \\
\text { reverse }\end{array}$ & $\begin{array}{l}\text { GCC AAC CCA GAG AAG AAG TG } \\
\text { CTG CTT AGG ACA AGA GCG AGA }\end{array}$ & BC102064 & 119 \\
\hline Complement factor 3 & $\begin{array}{l}\text { forward } \\
\text { reverse }\end{array}$ & $\begin{array}{l}\text { AAG TTC ATC ACC CAC ATC AAG } \\
\text { CAC TGT TTC TGG TTC TCC TC }\end{array}$ & NM001040469 & 191 \\
\hline Lactoferrin & $\begin{array}{l}\text { forward } \\
\text { reverse }\end{array}$ & $\begin{array}{l}\text { CGA AGT GTG GAT GGC AAG GAA } \\
\text { TTC AAG GTG GTC AAG TAG CGG }\end{array}$ & DQ522305 & 215 \\
\hline
\end{tabular}


eral target genes were chosen by screening the relevant literature.

The genes TLR 2 and TLR4 were chosen for their role in pathogen recognition and RelA for its role in signal transmission. Signaling pattern was represented by the cytokines TNF $\alpha$, IL-1 $\beta$, IL-6, and the chemokines IL-8 and RANTES. Two additional genes, C3 and lactoferrin, known to be important components of the innate immune defense of the udder, were also included. Further details of each of these genes and relevant citations to the literature are presented in the introduction.

\section{Data Analysis of Real-Time PCR}

For $\mathrm{C}_{\mathrm{T}}$ data analysis and to calculate the relative change of mRNA gene expression induced by the treatment, the well-established relative quantification method described by Livak and Schmittgen (2001) was used. The $\mathrm{C}_{\mathrm{T}}$ values of each target gene listed in Table 1 were normalized with respect to the arithmetic mean of 3 internally expressed reference genes, according to equation [1]. Suitable reference genes were selected and validated by GenEx software version 4.3.5 (MultiD Analyses AB, Göteborg, Sweden), namely, ubiquitin, GAPDH, and tyrosine 3-monooxygenase/tryptophan5monooxygenase activation protein:

$$
\Delta \mathrm{C}_{\mathrm{T}}=\mathrm{C}_{\mathrm{T} \text { (arithmetic mean of reference genes) }}-\mathrm{C}_{\mathrm{T} \text { (target gene) }} \text {. }
$$

To calculate the effect of treatment, the normalized gene expression values of nontreated control cells $\left[\Delta \mathrm{C}_{\mathrm{T} \text { (control cells })}\right]$ and treated cells $\left[\Delta \mathrm{C}_{\mathrm{T} \text { (treated cells) }}\right.$ either for 1-, 6-, or 24-h treatment] were set in relation, according to equation [2]:

$$
\Delta \Delta \mathrm{C}_{\mathrm{T}}=\Delta \mathrm{C}_{\mathrm{T} \text { (control cells) }}-\Delta \mathrm{C}_{\mathrm{T} \text { (treated cells) }} .
$$

To show the relative gene regulation (expression ratio) of the target genes, data were processed according to equation [3]:

$$
\text { Expression ratio }=2^{-\Delta \Delta \mathrm{CT}} .
$$

Target gene expressions are presented in tables as fold changes or expression ratio \pm standard error of the means compared with the untreated control. Values $>1.00$ represent an $\mathrm{x}$-fold upregulation through treatment, and values $<1.00$ represent a downregulation of the respective target gene.

Statistical analysis was carried out using the $\mathrm{R}$ programming language (R Development Core Team, 2008). The data were checked for normality and outliers using graphs as well as summary statistics. Accordingly, the Wilcoxon rank-sum test was chosen for the analysis of differences between factors. The null hypothesis of no difference in the mRNA expression between MAS-Q and MAS-q animals, as well as between CON-q and CON-Q animals, under control and treatment conditions was tested. The mRNA expression measures (ratios) were compared within time points of observation. A threshold $P$-value of 0.05 was used as a level of significance.

\section{RESULTS}

\section{Expression of mRNA in the MAS Groups}

Regarding pathogen-recognizing receptors, a significantly higher level of expression of TLR2 was detected for MAS-Q compared with MAS-q only after $24 \mathrm{~h}$, in both E. coli- and Staph. aureus-challenged cells (Figure 1; Table 2). No significant differences between MAS-Q and MAS-q could be noted for TLR4 and RelA (Table 2 ). Furthermore, differences between MAS-Q and MASq could be noted for several cytokines. Tumor necrosis factor- $\alpha$ and IL-1 $\beta$ showed, both in E. coli and Staph. aureus treatments after 6 as well as after $24 \mathrm{~h}$, a significantly increased transcription in the MAS-Q group compared with the MAS-q group (Figure 2; Table 2). For IL-6, a significantly higher mRNA expression was found in $E$. coli-challenged cells after $6 \mathrm{~h}$ in the MAS$\mathrm{q}$ group, and after $24 \mathrm{~h}$ in the MAS-Q group. Staph. aureus-challenged epithelial cells from MAS-Q animals showed a significantly higher expression level after 6 h (Table 2). The chemokine IL-8 showed a significant increase in expression level in E. coli as well as in Staph. aureus-affected cells in the MAS-Q group after 6 and 24 h (Figure 3; Table 2). A significantly higher expression in the MAS-Q group could be observed for RANTES both in E. coli- and Staph. aureus-challenged cells after $24 \mathrm{~h}$ (Table 2). The mRNA level of the effector molecules C3 and lactoferrin was significantly higher in the MAS-Q group after $24 \mathrm{~h}$ in both treatments applied (Figures 4 and 5; Table 2). No significant differences between MAS-Q and MAS-q individuals could be found for any of the measured factors in the base expression of untreated control cells (Table 3).

\section{Expression of mRNA of the CON Groups}

The pattern of response to pathogen challenge in the CON groups was similar to that in the MAS groups. The expression level of TLR2 (Figure 1) and TLR4 were higher in the CON-Q group, but no significant differences between CON-Q and CON-q could be detected for these factors (Table 2).

Both treatments induced a significantly higher expression of RelA in the CON-q than in the CON-Q group after $6 \mathrm{~h}$, whereas after $1 \mathrm{~h}$ only in $E$. coli, and 

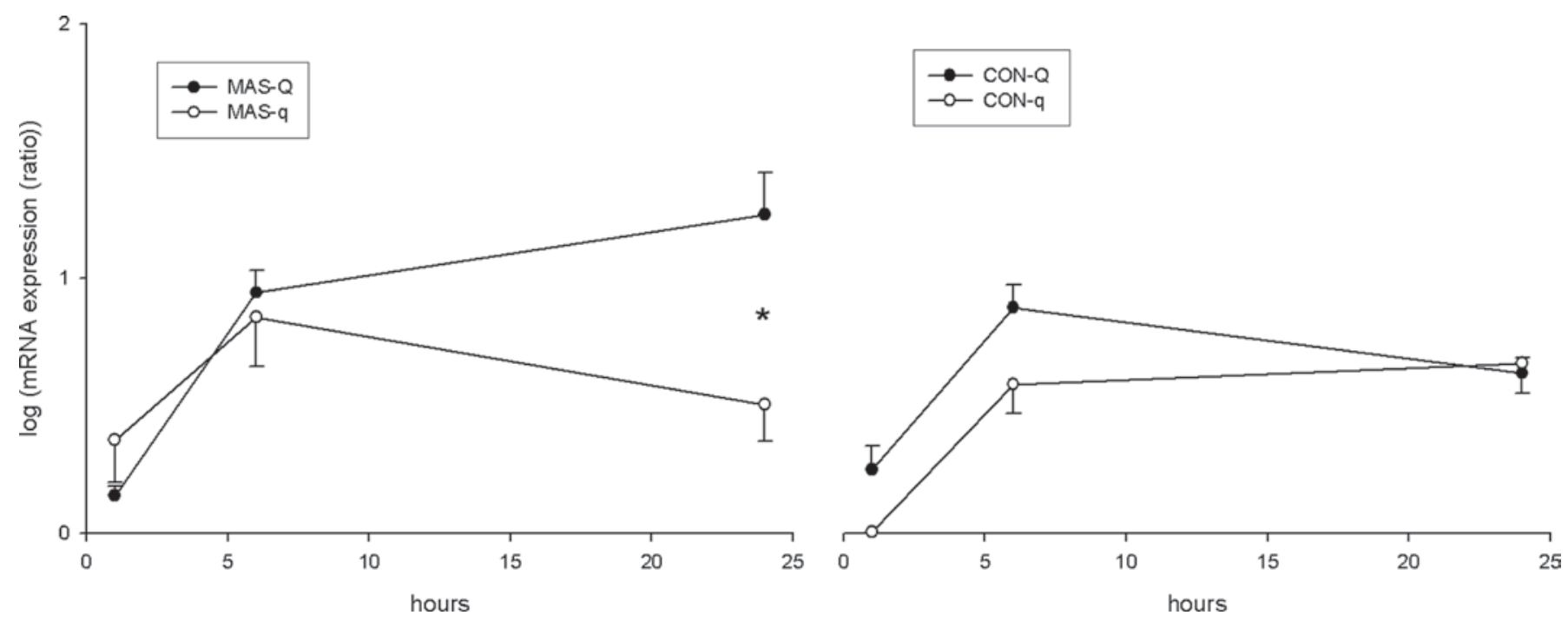

Figure 1. Pathogen recognition: mRNA expression (ratio) of toll-like-receptor 2 of the marker-assisted (MAS) and conventional (CON) selection groups after treatment with Escherichia coli for 1, 6, and $24 \mathrm{~h}$. Data are presented as means of ratios \pm SEM (log-transformation) of the target gene. Significant differences between cells isolated from more and less susceptible are indicated by $* P<0.05$. The CON strategy included 2 progeny groups originating from sires with extremely high (CON-Q) or extremely low (CON-q) relative EBV for SCS. The 2 MAS groups included heifers inheriting the paternal chromosomal region increasing (MAS-Q) or decreasing (MAS-q) SCS.

after 24 h only in Staph. aureus-treated cells, the mRNA level was significantly higher in the CON-Q group than in CON-q group (Table 2). For TNF- $\alpha$ (Figure 2) and IL-6 no significant differences between the CON-q and CON-Q were found (Table 2). In E. coli-treated cells, IL-1 $\beta$ showed a significantly increased mRNA level after $1 \mathrm{~h}$ in the CON-Q group (Table 2). No significant differences could be found for IL-8 (Table 2). Significant differences in the mRNA expression levels of RANTES were found only after $1 \mathrm{~h}$ of $E$. coli treatment (Table 2). Furthermore, C3 and lactoferrin showed no significant differences between CON-Q and CON-q (Figures 4 and 5; Table 2). Further, no significant differences between CON-Q and CON-q individuals could be found for any factors in the base expression of the untreated control cells (Table 3 ).

\section{DISCUSSION}

This experiment focuses on a QTL affecting the mammary gland immune system located on BTA 18 (Kühn et al., 2003). The results indicated that the mammary epithelial cells originating from animals selected according to the inherited QTL allele for udder health (MAS-Q and MAS-q) showed marked differences between groups. This could be confirmed based on the mRNA expression level of innate immune response genes after bacterial challenge. In contrast, almost no difference in response to mastitis pathogens could be observed between groups conventionally selected for low or high susceptibility to mastitis. It is worth mention- ing that animals from the MAS-Q and MAS-q groups comprised closely related half sibs, differing only in the QTL allele for SCC, which they were supposed to have inherited according to molecular marker information. In contrast, there was a strong genealogical difference between CON-Q and CON-q groups. Nevertheless, the CON groups proved to be less differentiated regarding response to pathogen challenge compared with the MAS groups. Thus, it can be assumed that the difference in the inherited QTL allele in the MAS groups is involved in the differences observed in response to bacterial challenge. Furthermore, these results give the first indication about the nature of molecular mechanisms underlying the QTL for udder health by highlighting the differences regarding early mechanisms of innate immunity in the mammary gland that are involved in mastitis resistance. The applied design of the cell culture model provides an appropriate tool to analyze individual differences in the immune response of genetically different cows under identical environmental conditions.

Several host factors, such as age of animal, number and stage of lactation, and SCS before infection are suggested to have influence on the course of infection in the mammary gland (Schukken et al., 1994; Burvenich et al., 2003). Numerous studies showed the association of mastitis with an elevated level of somatic cells in milk (Harmon, 1994; Mrode and Swanson, 1996; Klungland et al., 2001). For the stimulation of the epithelial cells, specific pathogenic Staph. aureus and E. coli strains were used to investigate the responses to both major forms of mastitis. The receptors TLR2 and 
Table 2. Expression of mRNA (ratio) in the marker-assisted (MAS) and conventionally (CON) selected groups ${ }^{1}$

$\begin{array}{llll} & 1 \mathrm{~h} & 6 \mathrm{~h}\end{array}$

$24 \mathrm{~h}$

\begin{tabular}{|c|c|c|c|c|c|c|c|c|}
\hline Target gene ${ }^{2}$ & Group & Challenge & $\mathrm{Q}$ & q & $\mathrm{Q}$ & $q$ & $\mathrm{Q}$ & $q$ \\
\hline \multirow[t]{4}{*}{ TLR 2} & MAS & Staph. aureus & $1.43 \pm 0.20$ & $2.18 \pm 0.55$ & $6.85 \pm 1.71$ & $5.55 \pm 1.63$ & $8.91 \pm 2.61^{* *}$ & $1.03 \pm 0.28$ \\
\hline & & E. coli & $1.41 \pm 0.13$ & $2.32 \pm 0.73$ & $8.81 \pm 1.94$ & $7.06 \pm 2.56$ & $17.86 \pm 8.25^{*}$ & $3.21 \pm 0.91$ \\
\hline & $\mathrm{CON}$ & Staph. aureus & $1.39 \pm 0.16$ & $1.31 \pm 0.19$ & $5.97 \pm 1.24$ & $3.92 \pm 0.95$ & $4.33 \pm 1.66$ & $2.76 \pm 0.61$ \\
\hline & & E. coli & $1.78 \pm 0.42$ & $1.01 \pm 0.10$ & $7.71 \pm 1.72$ & $3.85 \pm 0.90$ & $4.26 \pm 0.64$ & $4.66 \pm 1.12$ \\
\hline \multirow[t]{4}{*}{ TLR 4} & MAS & Staph. aureus & $1.09 \pm 0.06$ & $1.09 \pm 0.14$ & $1.41 \pm 0.22$ & $1.03 \pm 0.14$ & $1.54 \pm 0.33$ & $1.02 \pm 0.20$ \\
\hline & & E. coli & $1.10 \pm 0.15$ & $1.27 \pm 0.16$ & $1.51 \pm 0.14$ & $1.20 \pm 0.20$ & $1.82 \pm 0.37$ & $1.28 \pm 0.18$ \\
\hline & $\mathrm{CON}$ & Staph. aureus & $0.95 \pm 0.06$ & $1.01 \pm 0.14$ & $1.23 \pm 0.24$ & $0.84 \pm 0.10$ & $1.34 \pm 0.17$ & $0.95 \pm 0.09$ \\
\hline & & E. coli & $1.22 \pm 0.22$ & $0.79 \pm 0.08$ & $1.50 \pm 0.25$ & $1.15 \pm 0.10$ & $1.27 \pm 0.14$ & $1.02 \pm 0.17$ \\
\hline \multirow[t]{4}{*}{ RelA } & MAS & Staph. aureus & $1.13 \pm 0.07$ & $1.44 \pm 0.14$ & $0.82 \pm 0.06$ & $0.98 \pm 0.16$ & $1.12 \pm 0.11$ & $0.89 \pm 0.07$ \\
\hline & & E. coli & $1.40 \pm 0.17$ & $1.43 \pm 0.10$ & $0.91 \pm 0.06$ & $1.50 \pm 0.32$ & $0.80 \pm 0.07$ & $0.84 \pm 0.07$ \\
\hline & $\mathrm{CON}$ & Staph. aureus & $1.33 \pm 0.07^{* *}$ & $1.18 \pm 0.10$ & $0.82 \pm 0.06^{* *}$ & $1.05 \pm 0.07$ & $1.21 \pm 0.07$ & $0.85 \pm 0.06$ \\
\hline & & E. coli & $1.34 \pm 0.10^{*}$ & $1.02 \pm 0.8$ & $1.03 \pm 0.08^{*}$ & $1.46 \pm 0.16$ & $0.93 \pm 0.05$ & $0.88 \pm 0.07$ \\
\hline \multirow{4}{*}{ TNF- $\alpha$} & MAS & Staph. aureus & $7.67 \pm 2.90$ & $6.94 \pm 2.79$ & $32.89 \pm 8.71^{* *}$ & $7.01 \pm 2.64$ & $163.01 \pm 71.07^{* * *}$ & $8.07 \pm 3.55$ \\
\hline & & E. coli & $4.32 \pm 1.13$ & $2.89 \pm 1.06$ & $136.66 \pm 28.89^{* * *}$ & $27.18 \pm 11.31$ & $169.07 \pm 48.53^{* *}$ & $37.01 \pm 19.36$ \\
\hline & $\mathrm{CON}$ & Staph. aureus & $4.48 \pm 0.51$ & $11.61 \pm 2.51$ & $29.39 \pm 7.02$ & $18.72 \pm 6.01$ & $38.07 \pm 6.09$ & $31.86 \pm 11.83$ \\
\hline & & E. coli & $2.34 \pm 0.34$ & $2.35 \pm 0.46$ & $92.12 \pm 22.50$ & $50.98 \pm 13.77$ & $86.60 \pm 20.77$ & $43.45 \pm 13.40$ \\
\hline \multirow{4}{*}{ IL-1 $\beta$} & MAS & Staph. aureus & $2.78 \pm 0.55$ & $52.77 \pm 33.45$ & $488.51 \pm 163.12^{* *}$ & $135.93 \pm 80.71$ & $7,792.90 \pm 4.922 .18^{* *}$ & $237.89 \pm 153.76$ \\
\hline & & E. coli & $1.34 \pm 1.18$ & $11.62 \pm 7.03$ & $1,462.22 \pm 437.45^{* *}$ & $341.23 \pm 233.53$ & $15,868.67 \pm 8,092.34^{* *}$ & $2,503.77 \pm 1,633.41$ \\
\hline & $\mathrm{CON}$ & Staph. aureus & $2.99 \pm 0.62$ & $2.22 \pm 0.61$ & $738.40 \pm 176.80$ & $1,056.65 \pm 398.81$ & $1,904.57 \pm 1,585.61$ & $2,117.85 \pm 1,761.99$ \\
\hline & & E. coli & $1.33 \pm 0.16$ & $1.03 \pm 0.25$ & $2,543.84 \pm 717.16$ & $1,323 \pm 740.66$ & $1,158.70 \pm 252.04$ & $1.739 .07 \pm 688.16$ \\
\hline \multirow[t]{4}{*}{ IL-6 } & MAS & Staph. aureus & $1.54 \pm 0.26$ & $2.92 \pm 1.53$ & $7.18 \pm 2.90^{*}$ & $1.91 \pm 0.41$ & $367.53 \pm 235.59$ & $2.90 \pm 0.52$ \\
\hline & & E. coli & $1.10 \pm 0.16$ & $1.29 \pm 0.35$ & $0.92 \pm 0.13^{*}$ & $8.14 \pm 3.16$ & $19.47 \pm 9.22^{*}$ & $5.09 \pm 1.33$ \\
\hline & $\mathrm{CON}$ & Staph aureus & $3.34 \pm 0.90$ & $1.53 \pm 0.37$ & $7.07 \pm 2.07$ & $2.63 \pm 0.66$ & $11.04 \pm 4.33$ & $10.67 \pm 6.45$ \\
\hline & & E. coli & $2.37 \pm 0.70$ & $0.90 \pm 0.20$ & $74.34 \pm 58.97$ & $3.89 \pm 1.25$ & $20.36 \pm 8.69$ & $14.86 \pm 5.89$ \\
\hline \multirow{4}{*}{ IL-8 } & MAS & Staph. aureus & $11.01 \pm 5.57$ & $8.57 \pm 5.03$ & $18.11 \pm 8.04^{*}$ & $4.14 \pm 1.56$ & $769.99 \pm 424.01 *$ & $4.38 \pm 2.51$ \\
\hline & & E. coli & $3.25 \pm 0.74$ & $2.45 \pm 0.90$ & $75.29 \pm 29.44^{* *}$ & $11.21 \pm 4.21$ & $217.24 \pm 88.56^{* *}$ & $7.25 \pm 2.73$ \\
\hline & $\mathrm{CON}$ & Staph. aureus & $3.48 \pm 0.54$ & $4.95 \pm 1.40$ & $14.90 \pm 4.17$ & $6.34 \pm 2.11$ & $65.01 \pm 59.01$ & $46.09 \pm 40.15$ \\
\hline & & E. coli & $3.09 \pm 0.84$ & $1.90 \pm 0.43$ & $50.21 \pm 14.98$ & $14.82 \pm 4.57$ & $16.81 \pm 3.19$ & $14.44 \pm 4.09$ \\
\hline \multirow[t]{4}{*}{ RANTES } & MAS & Staph. aureus & $1.06 \pm 0.08$ & $3.27 \pm 2.09$ & $3.05 \pm 0.77$ & $2.40 \pm 0.70$ & $39.82 \pm 16.62 *$ & $2.43 \pm 0.71$ \\
\hline & & E. coli & $1.03 \pm 0.06$ & $1.68 \pm 0.61$ & $28.40 \pm 9.70$ & $15.50 \pm 6.20$ & $660.99 \pm 246.44^{*}$ & $173.02 \pm 112.04$ \\
\hline & $\mathrm{CON}$ & Staph. aureus & $1.25 \pm 0.09$ & $1.11 \pm 0.13$ & $2.58 \pm 0.38$ & $1.67 \pm 0.34$ & $3.13 \pm 0.56$ & $30.57 \pm 28.18$ \\
\hline & & E. coli & $1.38 \pm 0.20^{*}$ & $0.82 \pm 0.08$ & $46.58 \pm 15.09$ & $13.50 \pm 5.81$ & $185.83 \pm 70.37$ & $86.33 \pm 28.78$ \\
\hline \multirow{4}{*}{ Lactoferrin } & MAS & Staph. aureus & $1.02 \pm 0.08$ & $1.19 \pm 0.15$ & $1.69 \pm 0.26$ & $1.41 \pm 0.25$ & $7.65 \pm 1.44^{* * *}$ & $2.10 \pm 0.68$ \\
\hline & & E. coli & $1.58 \pm 0.29$ & $1.60 \pm 0.31$ & $1.65 \pm 0.21$ & $1.25 \pm 0.22$ & $5.60 \pm 1.31^{* *}$ & $1.90 \pm 0.72$ \\
\hline & $\mathrm{CON}$ & Staph. aureus & $1.18 \pm 0.9$ & $1.51 \pm 0.40$ & $1.93 \pm 0.29$ & $2.11 \pm 0.38$ & $8.37 \pm 1.37$ & $7.15 \pm 2.00$ \\
\hline & & E. coli & $1.69 \pm 0.13$ & $1.71 \pm 0.43$ & $1.48 \pm 0.20$ & $1.86 \pm 0.42$ & $5.35 \pm 1.46$ & $5.51 \pm 1.12$ \\
\hline \multirow{4}{*}{$\mathrm{C} 3$} & MAS & Staph. aureus & $1.38 \pm 0.28$ & $1.07 \pm 0.13$ & $2.30 \pm 0.32$ & $1.77 \pm 0.14$ & $4.31 \pm 0.53^{*}$ & $2.47 \pm 0.55$ \\
\hline & & E. coli & $1.57 \pm 0.23$ & $1.04 \pm 0.11$ & $2.08 \pm 0.20$ & $1.74 \pm 0.29$ & $5.50 \pm 1.24^{*}$ & $2.30 \pm 0.43$ \\
\hline & $\mathrm{CON}$ & Staph. aureus & $0.97 \pm 0.06$ & $0.90 \pm 0.09$ & $2.71 \pm 0.34$ & $2.23 \pm 0.41$ & $5.31 \pm 0.61$ & $4.27 \pm 1.10$ \\
\hline & & E. coli & $0.91 \pm 0.07$ & $0.86 \pm 0.07$ & $1.87 \pm 0.18$ & $2.61 \pm 0.56$ & $5.34 \pm 0.91$ & $4.90 \pm 0.99$ \\
\hline
\end{tabular}

${ }^{1}$ Data are shown as means of ratios \pm SEM of the target gene. The CON strategy included 2 progeny groups originating from sires with extremely high (CON-Q) or extremely low (CON-q) relative EBV for SCS. The 2 MAS groups included heifers inheriting the paternal chromosomal region increasing (MAS-Q) or decreasing (MAS-q) SCS.

${ }^{2} \mathrm{TLR}=$ toll-like receptor; RelA $=$ V-rel reticuloendotheliosis viral oncogene homolog A; TNF $=$ tumor necrosis factor; RANTES $=$ regulated upon activation, normal T-cell expressed and secreted; $\mathrm{C} 3=$ complement factor $\mathrm{C} 3$

${ }^{*} P<0.05,{ }^{* *} P<0.01$, and ${ }^{* * *} P<0.001$ indicate significant differences between $\mathrm{q}$ and $\mathrm{Q}$ groups. 

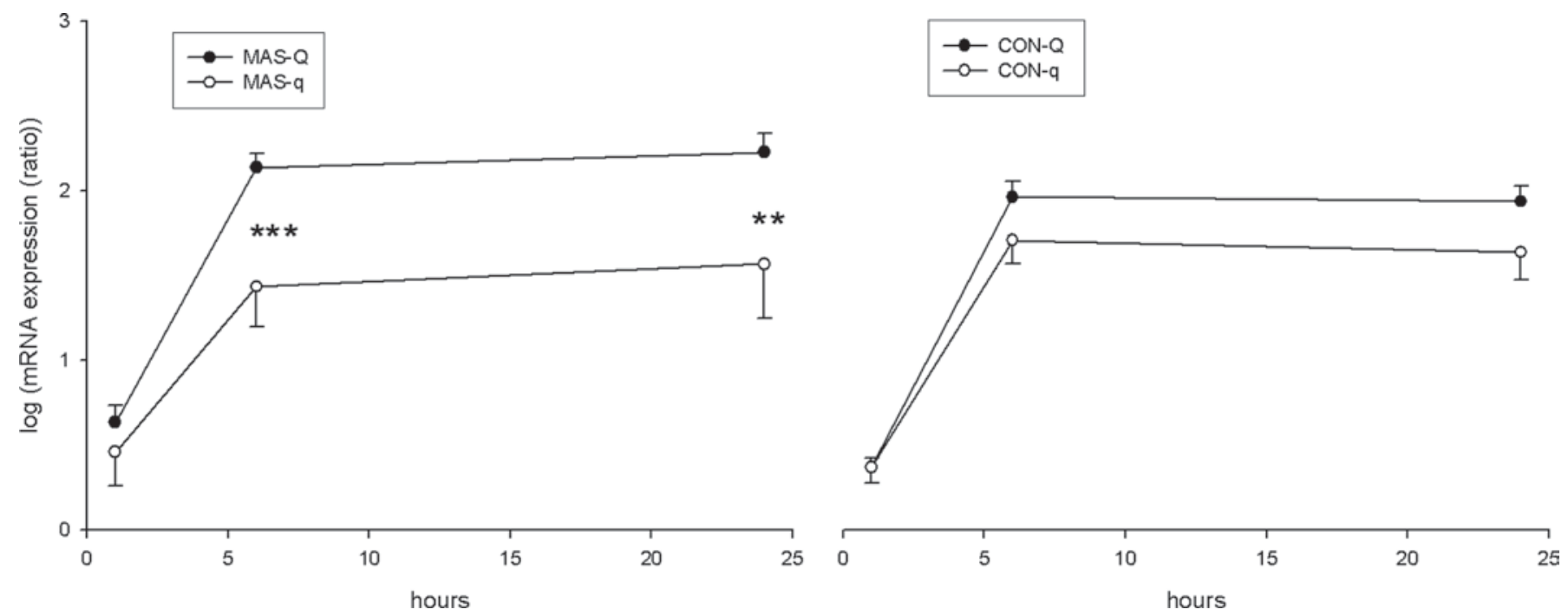

Figure 2. Cytokine: mRNA expression (ratio) of tumor necrosis factor- $\alpha$ of the marker-assisted (MAS) and conventional (CON) selection groups after treatment with Escherichia coli for 1, 6, and $24 \mathrm{~h}$. Data are presented as means of ratios \pm SEM (log-transformation) of the target gene. Significant differences between cells isolated from more and less susceptible are indicated by $* * P<0.01$ and $* * * P<0.001$. The CON strategy included 2 progeny groups originating from sires with extremely high (CON-Q) or extremely low (CON-q) relative EBV for SCS. The 2 MAS groups included heifers inheriting the paternal chromosomal region increasing (MAS-Q) or decreasing (MAS-q) SCS.

TLR4, which recognize conserved molecular patterns of invading pathogens, are key molecules of innate immune defense (Aderem and Ulevitch, 2000). In the mammary gland, TLR2 is activated by peptidoglycans and lipoteichoic acids that are cell-wall components of gram-positive bacteria; TLR4 is the main receptor for LPS characterizing gram-negatives but it is also activated by gram-positives (Strandberg et al., 2005).
A significant difference could be found for the mRNA expression of TLR2 between the MAS groups after 24 h of treatment both with E. coli and with Staph. aureus stimulation. This was caused by a marked decrease from 6 to $24 \mathrm{~h}$ in TLR2 expression in the MAS-q group. Generally, expression of both receptors was higher in more susceptible animals both in the CON and in the MAS groups. The relevance of TLR2 and TLR4

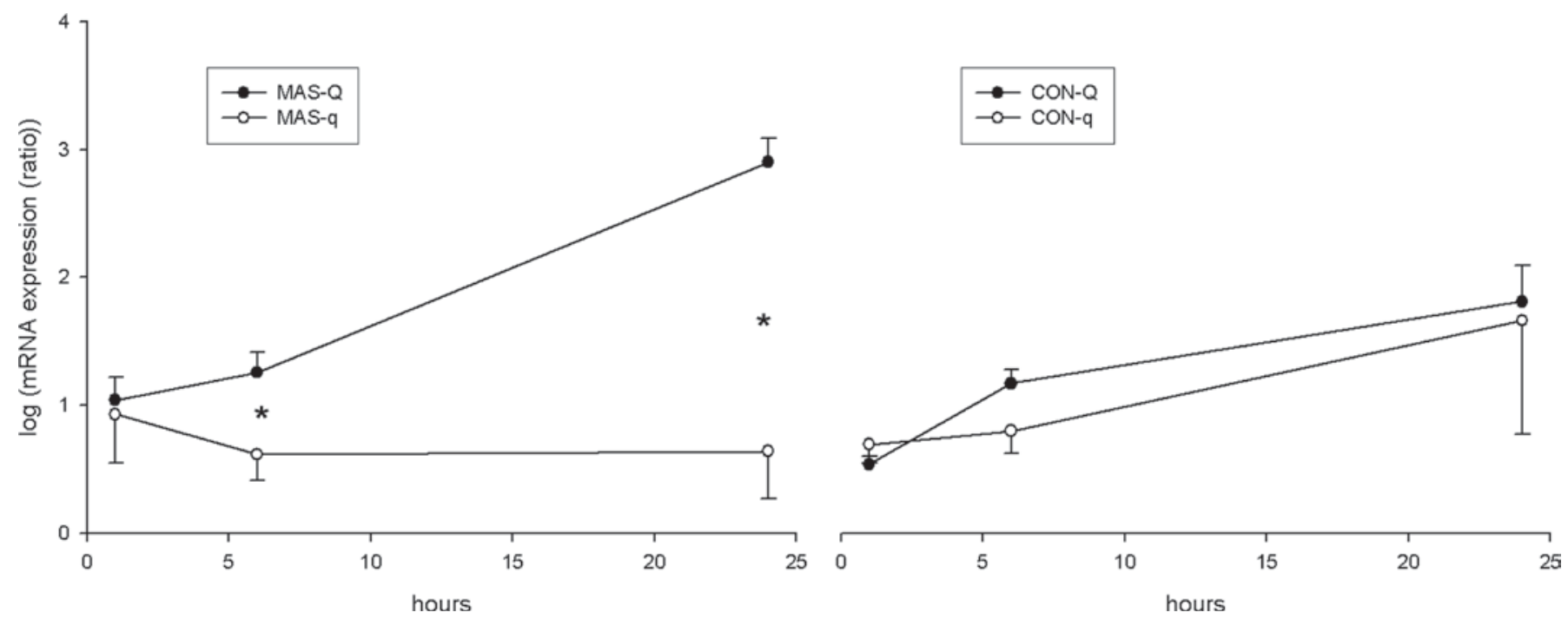

Figure 3. Chemokine: mRNA expression (ratio) of IL-8 of the marker-assisted (MAS) and conventional (CON) selection groups after treatment with Staphylococcus aureus for 1, 6, and $24 \mathrm{~h}$. Data are presented as means of ratios \pm SEM (log-transformation) of the target gene. Significant differences between cells isolated from more and less susceptible are indicated by $* P<0.05$. The CON strategy included 2 progeny groups originating from sires with extremely high (CON-Q) or extremely low (CON-q) relative EBV for SCS. The 2 MAS groups included heifers inheriting the paternal chromosomal region increasing (MAS-Q) or decreasing (MAS-q) SCS. 

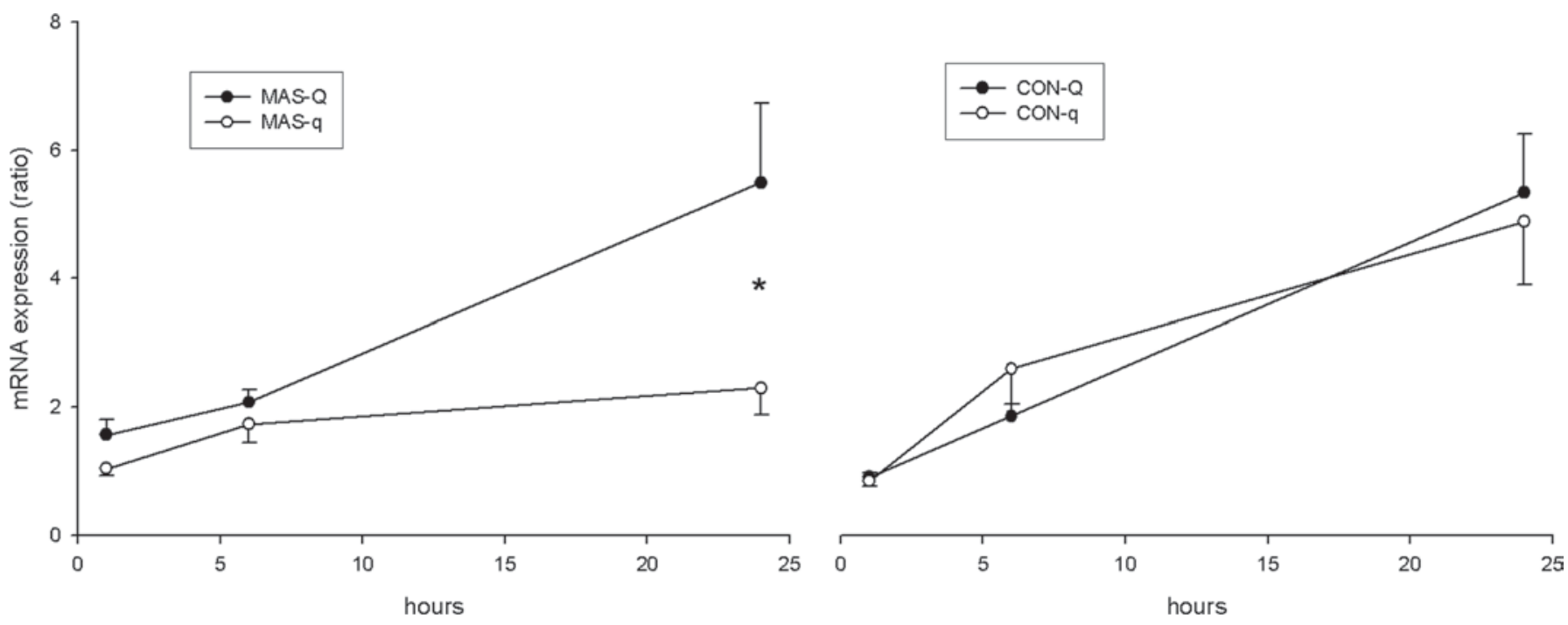

Figure 4. Complement system: mRNA expression (ratio) of complement factor 3 of the marker-assisted (MAS) and conventional (CON) selection groups after treatment with Escherichia coli for 1, 6, and $24 \mathrm{~h}$. Data are presented as means of the ratios \pm SEM of the target gene. Significant differences between cells isolated from more and less susceptible are indicated by $* P<0.05$. The CON strategy included 2 progeny groups originating from sires with extremely high (CON-Q) or extremely low (CON-q) relative EBV for SCS. The 2 MAS groups included heifers inheriting the paternal chromosomal region increasing (MAS-Q) or decreasing (MAS-q) SCS.

to susceptibility to infectious diseases was shown in a series of human studies, suggesting that genetic variations are responsible for a varied outcome of infectious diseases (Misch and Hawn, 2008). Human patients with a TLR2 mutation showed a higher prevalence of grampositive infections, whereas polymorphisms of TLR4 are associated with an increased number of sepsis cases (Lorenz et al., 2000, 2004). Differences in the expression pattern of TLR2 and TLR4 between more and less susceptible animals affirm the relevance of these factors to the course of infection in the mammary gland. The decrease in expression level of TLR2 and TLR4 during $24 \mathrm{~h}$ in the susceptible MAS-q group could be evidence for the crucial role of pathogen recognition in mastitis resistance.

In both CON and MAS groups, Staph. aureus and E. coli induced a similar profile of RelA, which is characterized by a decreasing expression of mRNA. However,

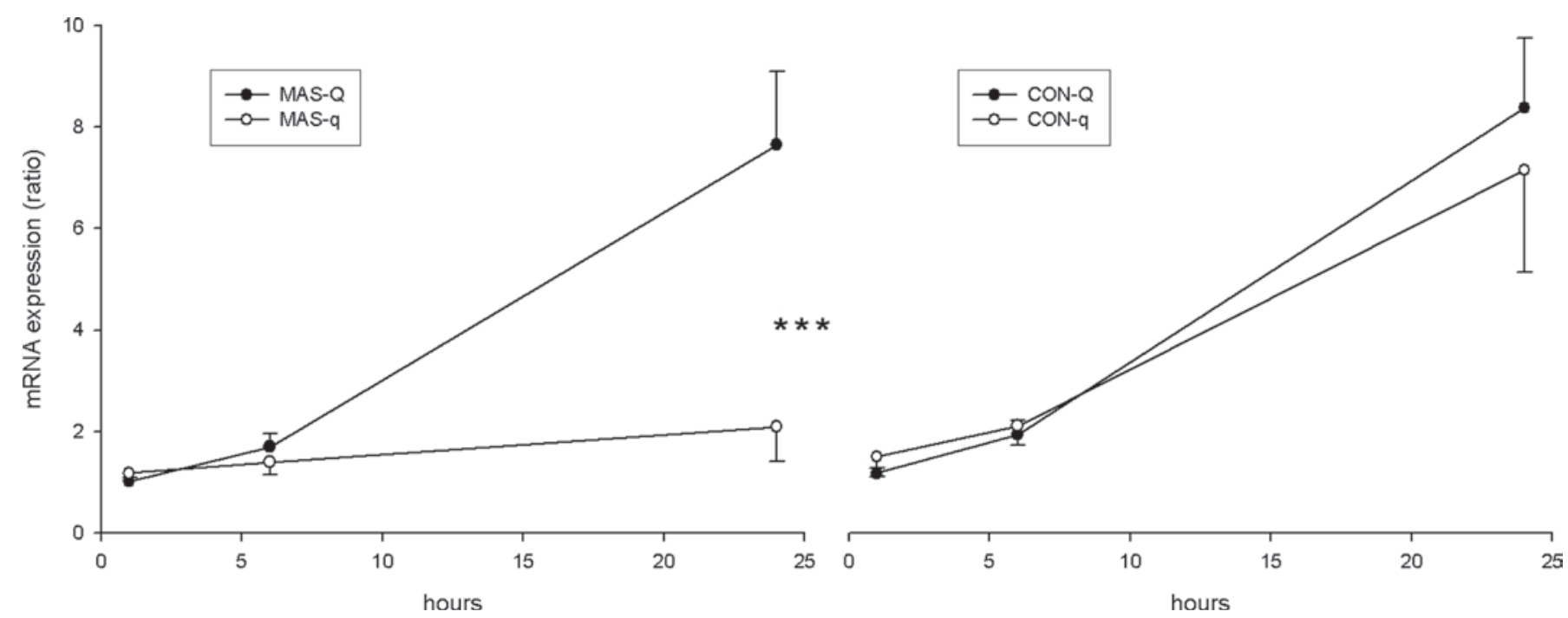

Figure 5. Lactoferrin: mRNA expression (ratio) of lactoferrin of the marker-assisted (MAS) and conventional (CON) selection groups after treatment with Staphylococcus aureus for 1, 6, and $24 \mathrm{~h}$. Data are presented as means of the ratios \pm SEM of the target gene. Significant differences between cells isolated from more and less susceptible are indicated by $* * * P<0.001$. The CON strategy included 2 progeny groups originating from sires with extremely high $(\mathrm{CON}-\mathrm{Q})$ or extremely low $(\mathrm{CON}-\mathrm{q})$ relative EBV for SCS. The 2 MAS groups included heifers inheriting the paternal chromosomal region increasing (MAS-Q) or decreasing (MAS-q) SCS. 
Table 3. Expression of mRNA $\left(\Delta \mathrm{C}_{\mathrm{T}}\right)$ of untreated control cells ${ }^{1}$

\begin{tabular}{llrr}
\hline & & \multicolumn{2}{c}{$\Delta \mathrm{C}_{\mathrm{T}} \pm \mathrm{SEM}$} \\
\cline { 3 - 4 } Target gene $^{2}$ & Group & $\mathrm{Q}$ & $\mathrm{q}$ \\
\hline TLR 2 & MAS & $9.91 \pm 1.10$ & $9.17 \pm 1.12$ \\
& CON & $9.35 \pm 1.50$ & $9.11 \pm 1.01$ \\
TLR 4 & MAS & $7.21 \pm 1.84$ & $6.42 \pm 1.06$ \\
& CON & $6.46 \pm 1.34$ & $6.20 \pm 0.82$ \\
RelA & MAS & $4.18 \pm 0.54$ & $3.93 \pm 0.31$ \\
& CON & $3.55 \pm 0.27$ & $4.06 \pm 0.56$ \\
TNF- $\alpha$ & MAS & $12.73 \pm 0.67$ & $11.06 \pm 1.51$ \\
& CON & $12.13 \pm 1.68$ & $11.82 \pm 1.91$ \\
IL-1 $\beta$ & MAS & $15.93 \pm 1.38$ & $12.72 \pm 2.90$ \\
& CON & $15.28 \pm 2.88$ & $12.66 \pm 3.70$ \\
IL-6 & MAS & $10.39 \pm 1.32$ & $8.58 \pm 1.67$ \\
& CON & $10.73 \pm 2.29$ & $9.55 \pm 1.53$ \\
IL-8 & MAS & $8.14 \pm 0.84$ & $5.59 \pm 2.22$ \\
& CON & $7.62 \pm 1.97$ & $6.00 \pm 2.37$ \\
RANTES & MAS & $8.46 \pm 1.35$ & $5.46 \pm 2.55$ \\
Lactoferrin & CON & $7.36 \pm 1.86$ & $6.63 \pm 1.94$ \\
& MAS & $3.45 \pm 2.015$ & $2.81 \pm 0.69$ \\
C3 & CON & $4.3 \pm 1.77$ & $4.16 \pm 1.19$ \\
& MAS & $5.35 \pm 1.10$ & $4.51 \pm 0.49$ \\
& CON & $4.86 \pm 0.86$ & $5.61 \pm 0.91$ \\
\hline
\end{tabular}

${ }^{1}$ Data are shown as means of $\Delta \mathrm{C}_{\mathrm{T}} \pm$ SEM of all time points of the target gene. The CON strategy included 2 progeny groups originating from sires with extremely high (CON-Q) or extremely low (CON-q) relative EBV for SCS. The 2 MAS groups included heifers inheriting the paternal chromosomal region increasing (MAS-Q) or decreasing (MAS-q) SCS.

${ }^{2} \mathrm{TLR}=$ toll-like receptor; RelA $=$ V-rel reticuloendotheliosis viral oncogene homolog A; TNF = tumor necrosis factor; RANTES $=$ regulated upon activation, normal T-cell expressed and secreted; C3 = complement factor C3.

significant differences were found only between the CON groups. Only limited information is available about the RelA mRNA expression pattern regarding infectious diseases, because most studies mainly analyzed its binding activity to DNA and regulation of gene expression (Liang et al., 2004; Boutet et al., 2007).

Tumor necrosis factor- $\alpha$, IL-1 $\beta$, IL-6, IL- 8 , and RANTES showed significant differences in mRNA expression between the MAS groups, and cells which were isolated from MAS-Q animals had the highest expression levels after $24 \mathrm{~h}$ of treatment. In the CON groups, only IL-1 $\beta$ and RANTES showed significant differences and the highest values were noted for IL-1 $\beta$, IL- 6 , and IL-8 in E. coli-treated cells after $6 \mathrm{~h}$. This is in accordance to the expression profile of TLR, indicating a strong correlation in the signaling pathway. Variability of cytokine production was found in human wholeblood samples after stimulation with LPS, indicating an individual inflammatory response (Wurfel et al., 2006). Furthermore, polymorphisms in both cytokines and chemokines are suggested to influence infectious diseases in humans (Stuber et al., 2005). These results demonstrate a higher immune response in the MAS-Q group. This may indicate a more effective elimination of pathogens in the mammary gland of these animals.
Complement factor $\mathrm{C} 3$ and lactoferrin are 2 additional molecules involved in the early immune defense of the udder (Hagiwara et al., 2003; Pfaffl et al., 2003; Rainard, 2003; Schmitz et al., 2004). Significant differences for these factors were noted only between the MAS groups, in which MAS-Q showed a significantly higher expression after $24 \mathrm{~h}$ for both treatments. Individual differences in the activation of the complement system are widely discussed in the literature regarding humans (Gadjeva et al., 2004). Variable synthesis of complement fragment C5a in the milk of cows was found (Rainard, 2005). One reason for this could be a difference in generating C5 convertase where C3 is involved, resulting in a more effective cleavage rate of $\mathrm{C} 5$. An increase of $\mathrm{C} 5 \mathrm{a}$, which acts as a chemotactic molecule, could result in improved recruitment and activation of neutrophils in the mammary gland (Shuster et al., 1997). Lactoferrin content in milk varies depending on the number and stage of lactation as well as depending on breed (Soyeurt et al., 2007). The expression profile of cells isolated from more susceptible animals is in line with these findings and emphasizes the relevance of lactoferrin to udder health.

\section{CONCLUSIONS}

A large number of significant differences between the MAS groups that are characterized by an elevation of mRNA expression in mammary epithelial cells isolated from animals of the MAS-Q group were noted. Essentially, the expression patterns of TLR and the measured cytokines as well as chemokines were found to be correlated. This correlation indicates a crucial role of pathogen recognition in influencing additional immunological processes, including linkage to the adaptive immune system. Further investigations are necessary to better understand the molecular linkage between regulation of TLR and the QTL on BTA 18 influencing SCS. A crucial limitation of current methods for selection based on EBV is the inability, caused by Mendelian segregation and independent assortment, to differentiate breeding values within progeny that share the same or similar pedigree. The promise of MAS and other genomic selection methods lies in their ability to transcend this limitation. The present study provides an evident example of this ability.

\section{ACKNOWLEDGMENTS}

This study was financially supported within the Funktionelle Genomanalyse im Tierischen Organismus (FUGATO) project MAS.net by the Förderverein Biotechnologie-Forschung (FBF) and the Federal Ministry of Education and Research (BMBF). The authors 
thank the laboratory staffs of the Research Institute for the Biology of Farm Animals, Dummerstorf, and of Veterinary Physiology, Bern, for their hospitality and assistance. Finally, we are grateful to the reviewers of the Journal of Dairy Science for their great efforts with this paper. Their constructive and careful correction was instrumental in preparing this manuscript.

\section{REFERENCES}

Aderem, A., and R. J. Ulevitch. 2000. Toll-like receptors in the induction of the innate immune response. Nature 406:782-787.

Bannerman, D. D., M. J. Paape, J. W. Lee, X. Zhao, J. C. Hope, and P. Rainard. 2004. Escherichia coli and Staphylococcus aureus elicit differential innate immune responses following intramammary infection. Clin. Diagn. Lab. Immunol. 11:463-472.

Boudjellab, N., H. S. Chan-Tang, and X. Zhao. 2000. Bovine interleukin-1 expression by cultured mammary epithelial cells (MAC-T) and its involvement in the release of MAC-T derived interleukin-8. Comp. Biochem. Physiol. A 127:191-199.

Boutet, P., J. Sulon, R. Closset, J. Detilleux, J. F. Beckers, F. Bureau, and P. Lekeux. 2007. Prolactin-induced activation of nuclear factor kappaB in bovine mammary epithelial cells: role in chronic mastitis. J. Dairy Sci. 90:155-164.

Bramley, A. J., A. H. Patel, M. O'Reilly, R. Forster, and T. J. Forster. 1989. Roles of alpha-toxin and beta-toxin in virulence of Staphylococcus aureus for the mouse mammary gland. Infect. Immun. 57:2489-2494.

Burvenich, C., V. Van Merris, J. Mehrzad, A. Diez-Fraile, and L. Duchateau. 2003. Severity of E. coli mastitis is mainly determined by cow factors. Vet. Res. 34:521-564.

Fernando, R. L., and M. Grossman. 1989. Marker assisted selection using best linear unbiased prediction. Genet. Sel. Evol. 21:467477 .

Gadjeva, M., K. Takahashi, and S. Thiel. 2004. Mannan-binding lectin-A soluble pattern recognition molecule. Mol. Immunol. 41:113-121.

Hagiwara, S., K. Kawai, A. Anri, and H. Nagahata. 2003. Lactoferrin concentrations in milk from normal and subclinical mastitic cows. J. Vet. Med. Sci. 65:319-323.

Harmon, R. J. 1994. Physiology of mastitis and factors affecting somatic cell counts. J. Dairy Sci. 77:2103-2112.

Hinrichs, D., E. Stamer, W. Junge, and E. Kalm. 2005. Genetic analyses of mastitis data using animal threshold models and genetic correlation with production traits. J. Dairy Sci. 88:2260-2268.

Khatkar, M. S., P. C. Thomson, I. Tammen, and H. W. Raadsma 2004. Quantitative trait loci mapping in dairy cattle: Review and meta-analysis. Genet. Sel. Evol. 36:163-190.

Klungland, H., A. Sabry, B. Heringstad, H. G. Olsen, L. Gomez-Raya, D. I. Våge, I. Olsaker, J. Ødegård, G. Klemetsdal, N. Schulman, J. Vilkki, J. Ruane, M. Aasland, K. Rønningen, and S. Lien. 2001 Quantitative trait loci affecting clinical mastitis and somatic cell count in dairy cattle. Mamm. Genome 12: 837-842.

Korhonen, H., P. Marnila, and H. S. Gill. 2000. Milk immunoglobulins and complement factors. Br. J. Nutr. 84(Suppl. 1):75-80.

Kühn, Ch., J. Bennewitz, N. Reinsch, N. Xu, H. Thomsen, C. Looft, G. A. Brockmann, M. Schwerin, C. Weimann, S. Hiendleder, G. Erhardt, I. Medjugorac, M. Förster, B. Brenig, F. Reinhardt, R. Reents, I. Russ, G. Averdunk, J. Blümel, and E. Kalm. 2003. Quantitative trait loci mapping of functional traits in the German Holstein cattle population. J. Dairy Sci. 86:360-368.

Kühn, Ch., F. Reinhardt, and M. Schwerin. 2008. Marker assisted selection of heifers improved milk somatic cell count compared to selection on conventional pedigree breeding values. Arch. Tierz. Dummerstorf 51:23-32.

Liang, Y., Y. Zhou, and P. Shen. 2004. NF-kappaB and its regulation on the immune system. Cell. Mol. Immunol. 1:343-350.
Livak, K. J., and T. D. Schmittgen. 2001. Analysis of relative gene expression data using real-time quantitative PCR and the 2(-Delta Delta C(T)) method. Methods. 25:402-408.

Lorenz, E., J. P. Mira, K. L. Cornish, N. C. Arbour, and D. A Schwartz. 2000. A novel polymorphism in the toll-like receptor 2 gene and its potential association with staphylococcal infection. Infect. Immun. 68:6398-6401.

Lorenz, E., J. P. Mira, K. L. Frees, and D. A. Schwartz. 2004. Relevance of mutations in the TLR4 receptor in patients with gram-negative septic shock. Arch. Intern. Med. 162:1028-1032.

Miglior, F., B. L. Muir, and B. J. Van Doormaal. 2005. Selection indices in Holstein cattle of various countries. J. Dairy Sci. $88: 1255-1263$.

Misch, E. A., and T. R. Hawn. 2008. Toll-like receptor polymorphisms and susceptibility to human disease. Clin. Sci. (Lond.) 114:347360.

Mrode, R. A., and G. J. T. Swanson. 1996. Genetic and statistical properties of somatic cell counts and its suitability as an indirect means of reducing the incidence of mastitis in dairy cattle. Anim. Breed. Abstr. 64:847-857.

Pahl, H. L. 1999. Activators and target genes of Rel/NF-kappaB transcription factors. Oncogene 18:6853-6866.

Pareek, R., O. Wellnitz, R. van Dorp, J. Burton, and D. Kerr. 2005. Immunorelevant gene expression in LPS-challenged bovine mammary epithelial cells. J. Appl. Genet. 46:171-177.

Persson Waller, K., I. G. Colditz, S. Lun, and K. Ostensson. 2003. Cytokines in mammary lymph and milk during endotoxin-induced bovine mastitis. Res. Vet. Sci. 74:31-36.

Pfaffl, M. W., S. L. Wittmann, H. H. Meyer, and R. M. Bruckmaier. 2003. Gene expression of immunologically important factors in blood cells, milk cells, and mammary tissue of cows. J. Dairy Sci. 86:538-545.

R Development Core Team. 2008. R: A Language and Environment for Statistical Computing. R Foundation for Statistical Computing, Vienna, Austria. http://www.R-project.org.

Rainard, P. 2003. The complement in milk and defense of the bovine mammary gland against infections. Vet. Res. 34:647-670.

Rainard, P. 2005. Tackling mastitis in dairy cows. Nat. Biotechnol. $23: 430-432$

Rainard, P., and C. Riollet. 2006. Innate immunity of the bovine mammary gland. Vet. Res. 37:369-400.

Riollet, C., P. Rainard, and B. Poutrel. 2000. Differential induction of complement fragment C5a and inflammatory cytokines during intramammary infections with Escherichia coli and Staphylococcus aureus. Clin. Diagn. Lab. Immunol. 7:161-167.

Rupp, R., and D. Boichard. 2003. Genetics of resistance to mastitis in dairy cattle. Vet. Res. 34:671-688.

Schmitz, S., M. W. Pfaffl, H. H. Meyer, and R. M. Bruckmaier. 2004. Short-term changes of mRNA expression of various inflammatory factors and milk proteins in mammary tissue during LPS-induced mastitis. Domest. Anim. Endocrinol. 26:111-126.

Schukken, Y. H., B. A. Mallard, J. C. Dekkers, K. E. Leslie, and M. J. Stear. 1994. Genetic impact on the risk of intramammary infection following Staphylococcus aureus challenge. J. Dairy Sci. 77:639-647.

Schulman, N. F., S. M. Viitala, D. J. de Koning, J. Virta, A. Makitanila, and J. H. Vilkki. 2004. Quantitative trait loci for health traits in Finnish Ayrshire cattle. J. Dairy Sci. 87:443-449.

Seegers, H., C. Fourichon, and F. Beaudeau. 2003. Production effects related to mastitis and mastitis economics in dairy cattle herds. Vet. Res. 34:475-491.

Shuster, D. E., M. E. Jr. Kehrli, P. Rainard, and M. Paape. 1997. Complement fragment $\mathrm{C} 5 \mathrm{a}$ and inflammatory cytokines in neutrophil recruitment during intramammary infection with Escherichia coli. Infect. Immun. 65:3286-3292.

Soyeurt, H., F. G. Colinet, V. M. Arnould, P. Dardenne, C. Bertozzi, R. Renaville, D. Portetelle, and N. Gengler. 2007. Genetic variability of lactoferrin content estimated by mid-infrared spectrometry in bovine milk. J. Dairy Sci. 90:4443-4445.

Strandberg, Y., C. Gray, T. Vuocolo, L. Donaldson, M. Broadway, and R. Tellam. 2005. Lipopolysaccharide and lipoteichoic acid induce 
different innate immune responses in bovine mammary epithelial cells. Cytokine 31:72-86.

Stuber, F., S. Klaschik, L. E. Lehmann, J. C. Schewe, S. Weber, and M. Book. 2005. Cytokine promoter polymorphisms in severe sepsis. Clin. Infect. Dis. 41(Suppl. 7):416-420.

Weikard, R., C. Kühn, T. Goldammer, G. Freyer, and M. Schwerin. 2005. The bovine PPARGC1A gene: Molecular characterization and association of an SNP with variation of milk fat synthesis. Physiol. Genomics 21:1-3.

Wellnitz, O., and D. E. Kerr. 2004. Cryopreserved bovine mammary cells to model epithelial response to infection. Vet. Immunol. Immunopathol. 101:191-202.

Wellnitz, O., P. Reith, and H. H. D. Meyer. 2006. Immune relevant gene expression of mammary epithelial cells and their influence on leukocyte chemotaxis in response to different mastitis pathogens. Vet. Med. Czech 51:125-132.
Wilkens, J., A. Bünger, and F. Reinhardt. 2006. Marker assisted selection in German Holsteins. Proc. 10th QTL-MAS Workshop, Salzburg, Austria.

Wurfel, M. M., W. Y. Park, F. Radella, J. Ruzinski, A. Sandstrom, J. Strout, R.E. Bumgarner, and T. R. Martin. 2006. Identification of high and low responders to lipopolysaccharide in normal subjects: An unbiased approach to identify modulators of innate immunity. J. Immunol. 175: 2570-2578.

Xu, N. Y., S. Paul, J. Bennewitz, N. Reinsch, G. Thaller, F. Reinhard, Ch. Kühn, M. Schwerin, G. Erhardt, C. Weimann, N. Thomsen, S. Mishra, and E. Kalm. 2006. Conformation of quantitative trait loci for somatic cell score on bovine chromosome 18 in the German Holstein. Arch. Tierzucht. 49:111-119. 